\title{
Influence of a Ni Foil Interlayer on Interface Properties of Mg-Clad Al Materials by Vacuum Roll Bonding
}

\author{
Jinfeng Shu, Tomiko Yamaguchi* and Yuya Hara \\ Department of Materials Science, Graduate School of Engineering, Kyushu Institute of Technology, Kitakyushu 804-0015, Japan
}

\begin{abstract}
Mg-clad Al materials with a Ni foil interlayer were successfully prepared by vacuum roll bonding at a $450^{\circ} \mathrm{C}$ rolling temperature and $25 \%$ reduction, and the effects of the $\mathrm{Ni}$ foil interlayer on the interfacial properties were investigated. The clad materials with the Ni foil interlayer only formed the $\mathrm{Mg}_{2} \mathrm{Ni}$ intermetallic compound with a $0.9 \mu \mathrm{m}$ thickness on the $\mathrm{Mg}-\mathrm{Ni}$ interface, which was smaller than that of the intermetallic compounds $\left(\mathrm{Al}_{12} \mathrm{Mg}_{17}\right.$ of $1.77 \mu \mathrm{m}$ and $\mathrm{Al}_{3} \mathrm{Mg}_{2}$ of $\left.7.76 \mu \mathrm{m}\right)$ formed on the $\mathrm{Al}-\mathrm{Mg}$ interface without the interlayer. The bonding strength of the interface increased from $0.79 \mathrm{MPa}$ to $10.46 \mathrm{MPa}$. The growth characteristics of the $\mathrm{Mg}_{2} \mathrm{Ni}$ intermetallic compound on the $\mathrm{Mg}-\mathrm{Ni}$ interface after heat treatment were investigated. The growth activation energy of $\mathrm{Mg}_{2} \mathrm{Ni}$ was $157.24 \mathrm{~kJ} / \mathrm{mol}$, which is higher than that of $\mathrm{Al}_{3} \mathrm{Mg}_{2}$ which mainly affects the $\mathrm{Al}-\mathrm{Mg}$ interfacial bonding strength. Therefore, the thickness of the $\mathrm{Mg}_{2} \mathrm{Ni}$ was thinner and the interfacial bonding strength was greater after the vacuum roll bonding. [doi:10.2320/matertrans.MT-M2019277]
\end{abstract}

(Received September 27, 2019; Accepted February 3, 2020; Published March 6, 2020)

Keywords: vacuum roll bonding, Mg-clad Al materials, Ni foil interlayer, intermetallic compounds, growth activation energy

\section{Introduction}

Magnesium (Mg) alloys are currently some of the most widely used eco-friendly structural materials because of their high specific strength, low density and recyclability. They have broad application prospects in the fields of automobiles, aerospace and biomaterials. However, $\mathrm{Mg}$ alloys have a poor corrosion resistance due to their electrochemical property. ${ }^{1-4)}$ Therefore, improving the corrosion resistance of $\mathrm{Mg}$ alloys and the application scope have become a very meaningful subject to investigate.

In recent years, clad materials have attracted much attention because of their excellent overall performance. They can be used to manufacture industrial parts with different internal and external properties. Therefore, they are widely used in mobile phones, automobiles, aviation, electronics and medical devices. ${ }^{5-7}$ ) Aluminum (Al) is a low density and high strength material with an excellent corrosion resistance. It can effectively improve the corrosion resistance of $\mathrm{Mg}$ alloys by cladding an $\mathrm{Al}$ layer on the $\mathrm{Mg}$ alloy's surface to avoid direct contact between the $\mathrm{Mg}$ alloys and corrosion medium. ${ }^{8,9)}$ Roll bonding is one of the important technologies for preparing clad materials. ${ }^{10)}$ However, the surfaces of the $\mathrm{Al}$ and $\mathrm{Mg}$ sheets are prone to form oxide films during the hot roll bonding, which leads to difficulties in joining dissimilar materials. In this study, in order to avoid the formation of oxide films, the roll bonding will be carried out in a vacuum environment.

During the process of preparing $\mathrm{Mg}$-clad Al materials by roll bonding, $\mathrm{Al}-\mathrm{Mg}$ intermetallic compounds are easily formed on the $\mathrm{Al}-\mathrm{Mg}$ interface. The intermetallic compounds are hard and brittle, which significantly affects the interfacial bonding strength. ${ }^{11)}$ In order to reduce the influences of the $\mathrm{Al}-\mathrm{Mg}$ intermetallic compounds, the most effective method is to avoid direct contact between the $\mathrm{Al}$ and $\mathrm{Mg}$ sheets by adding an interlayer. ${ }^{6}$ ) Since the growth activation energies of the intermetallic compounds $\mathrm{Mg}_{2} \mathrm{Ni}$ and $\mathrm{MgNi}_{2}$ which may be formed on the $\mathrm{Mg}-\mathrm{Ni}$ interface, and $\mathrm{Al}_{3} \mathrm{Ni}$ and

*Corresponding author, E-mail: yamaguchi.tomiko374@mail.kyutech.jp
$\mathrm{Al}_{3} \mathrm{Ni}_{2}$ which may be formed on the $\mathrm{Al}-\mathrm{Ni}$ interface are higher than those of the $\mathrm{Al}-\mathrm{Mg}$ intermetallic compounds, the adverse effect on the interface properties may be smaller. ${ }^{12-16)}$ Therefore, Ni foil was used as the interlayer to study the effects of the $\mathrm{Ni}$ interlayer on the $\mathrm{Al}-\mathrm{Mg}$ interface in this study.

\section{Experimental Procedure}

The materials used in the experiment were magnesium alloy AZ31 sheets ( $\mathrm{Mg}$ sheets) with the size of $1.5 \mathrm{~mm} \times$ $65 \mathrm{~mm} \times 200 \mathrm{~mm}$, pure aluminum A1050 sheets (Al sheets) with the size of $3 \mathrm{~mm} \times 80 \mathrm{~mm} \times 300 \mathrm{~mm}$ and $10 \mu \mathrm{m}$ thick pure $\mathrm{Ni}$ foil. In order to prevent the bending of the $\mathrm{Al}$ and $\mathrm{Mg}$ sheets during rolling, steel SS400 sheets (Fe sheets) with the size of $8 \mathrm{~mm} \times 80 \mathrm{~mm} \times 300 \mathrm{~mm}$ were used for rolling together with the $\mathrm{Al}$ and $\mathrm{Mg}$ sheets. The $\mathrm{Al}$ and $\mathrm{Mg}$ sheets were annealed for $30 \mathrm{~min}$ at $350^{\circ} \mathrm{C}$ and $400^{\circ} \mathrm{C}$, respectively. Before the experiment, the oxide films were removed from the $\mathrm{Al}$ and $\mathrm{Mg}$ sheet surfaces by a steel brush and 2000\# sandpaper, respectively. Using $\mathrm{Ni}$ foil as the interlayer of the $\mathrm{Al}$ and $\mathrm{Mg}$ sheets, the materials were heated to $450^{\circ} \mathrm{C}$ by high frequency induction under a $6 \times 10^{-3} \mathrm{~Pa}$ vacuum environment and entered the bonding rolls. The heating time was $30 \mathrm{~min}$ to ensure that there was enough time for heat conduction to keep the temperature between the $\mathrm{Al}$ and $\mathrm{Mg}$ sheets consistent. The reduction was set to $25 \%$ (refers to the total reduction of the $\mathrm{Al}$ and $\mathrm{Mg}$ sheets). After rolling, the clad materials were cooled in a vacuum. Figure 1 shows a schematic diagram of the vacuum rolling equipment used in the experiment. The effects of the $\mathrm{Ni}$ foil interlayer on the $\mathrm{Al}-\mathrm{Mg}$ interfacial properties were investigated by scanning electron microscopy (SEM), energy dispersive x-ray spectrometry (EDS), electron probe $\mathrm{x}$-ray micro-analyzer (EPMA), X-ray diffraction (XRD) and a TCE-N300 tensile testing machine. As a comparison, the experiments without the $\mathrm{Ni}$ foil interlayer were also carried out under the same conditions. Figure 2 shows the tensile test of the interfacial bonding strength. 


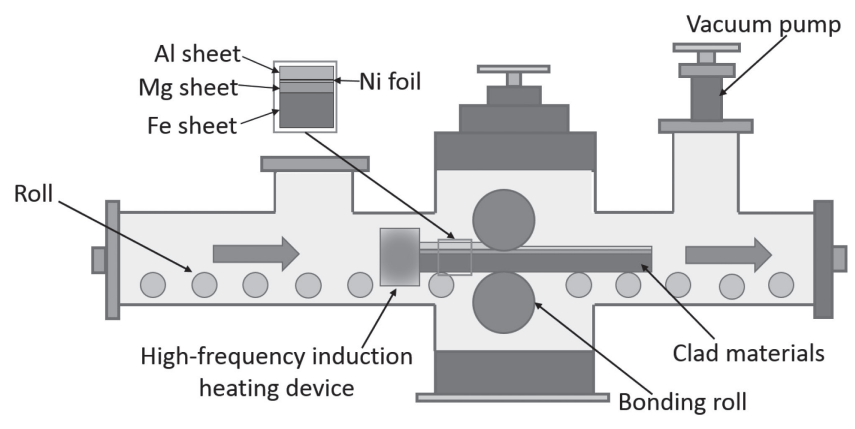

Fig. 1 Schematic diagram of the vacuum rolling equipment.

The Mg-clad Al materials with the $\mathrm{Ni}$ foil interlayer prepared by vacuum roll bonding were heat treated at $623 \mathrm{~K}$ $\left(350^{\circ} \mathrm{C}\right), 673 \mathrm{~K}\left(400^{\circ} \mathrm{C}\right)$ and $703 \mathrm{~K}\left(430^{\circ} \mathrm{C}\right)$ in a muffle furnace. The growth characteristics of the intermetallic compounds on the interface after heat treatment were investigated.

\section{Results and Discussion}

After vacuum roll bonding without any interlayer, the interfacial properties were analyzed. Figure 3(a) shows an SEM image of the Al-Mg interface. It can be seen that about $10 \mu \mathrm{m}$ a reaction layer was formed on the $\mathrm{Al}-\mathrm{Mg}$ interface. The EDS line-scanning for the interface was performed, and the results are shown in Fig. 3(b). It is shown that the reaction layer was divided into two layers with different
$\mathrm{Al}-\mathrm{Mg}$ compositions. Based on the $\mathrm{Al}-\mathrm{Mg}$ equilibrium phase diagram, ${ }^{17)}$ the atomic ratio of $\mathrm{Al}$ to $\mathrm{Mg}$ in the reaction layer connecting the $\mathrm{Mg}$ side is close to $\mathrm{Al}_{12} \mathrm{Mg}_{17}$, and that of $\mathrm{Al}$ to $\mathrm{Mg}$ in the reaction layer connecting the $\mathrm{Al}$ side is close to $\mathrm{Al}_{3} \mathrm{Mg}_{2}$, with a thickness of $1.77 \mu \mathrm{m}$ and $7.76 \mu \mathrm{m}$, respectively. This indicated that two layers of intermetallic compounds, $\mathrm{Al}_{12} \mathrm{Mg}_{17}$ and $\mathrm{Al}_{3} \mathrm{Mg}_{2}$, were formed on the $\mathrm{Al}-\mathrm{Mg}$ interface after vacuum roll bonding. The bonding strength of the interface was $0.79 \mathrm{MPa}$ by the tensile test on the clad materials. The intermetallic compounds are hard and brittle, and the hardness of the $\mathrm{Al}_{3} \mathrm{Mg}_{2}$ and $\mathrm{Al}_{12} \mathrm{Mg}_{17}$ reached HV415 and HV383, respectively. ${ }^{18)}$ Considering that the intermetallic compounds layer on the $\mathrm{Al}-\mathrm{Mg}$ interface have a significant influence on the bonding strength, the bonding strength was very low.

The morphology of the fracture surface for the Al-Mg interface without the interlayer is shown in Fig. 4(a). The typical morphology of the brittle cleavage fracture is observed on the fracture surface, which is relatively flat and there are some cleavage steps. Based on Fig. 4(b), the atomic percentages of the $\mathrm{Al}$ and $\mathrm{Mg}$ elements on the fracture surface are $60.16 \%$ and $39.18 \%$, respectively, which are close to $\mathrm{Al}_{3} \mathrm{Mg}_{2}$. Therefore, it can be inferred that the fracture mainly occurred in the $\mathrm{Al}_{3} \mathrm{Mg}_{2}$ layer during the tensile test and was brittle fracture. As shown in Fig. 3(b), considering that the thickness of the $\mathrm{Al}_{3} \mathrm{Mg}_{2}$ is greater than that of $\mathrm{Al}_{12} \mathrm{Mg}_{17}$, and the hardness of $\mathrm{Al}_{3} \mathrm{Mg}_{2}$ is also greater than that of $\mathrm{Al}_{12} \mathrm{Mg}_{17}$, the formation and propagation of cracks mainly occurred in the $\mathrm{Al}_{3} \mathrm{Mg}_{2}$ layer.
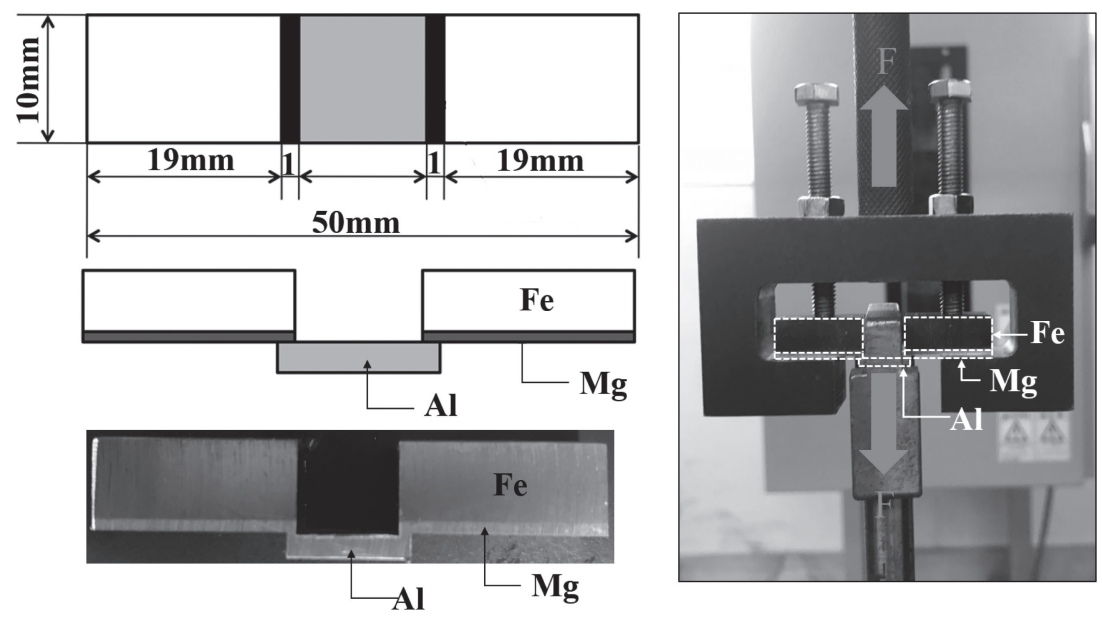

Fig. 2 Tensile test of the interfacial bonding strength.
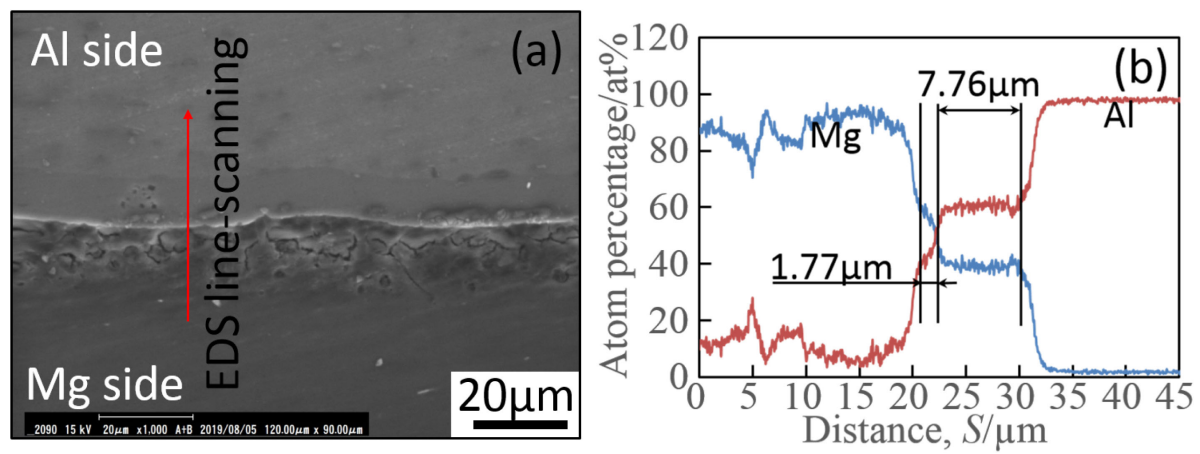

Fig. 3 (a) SEM image of the Al-Mg interface without the interlayer and (b) EDS line-scanning profile for the interface. 

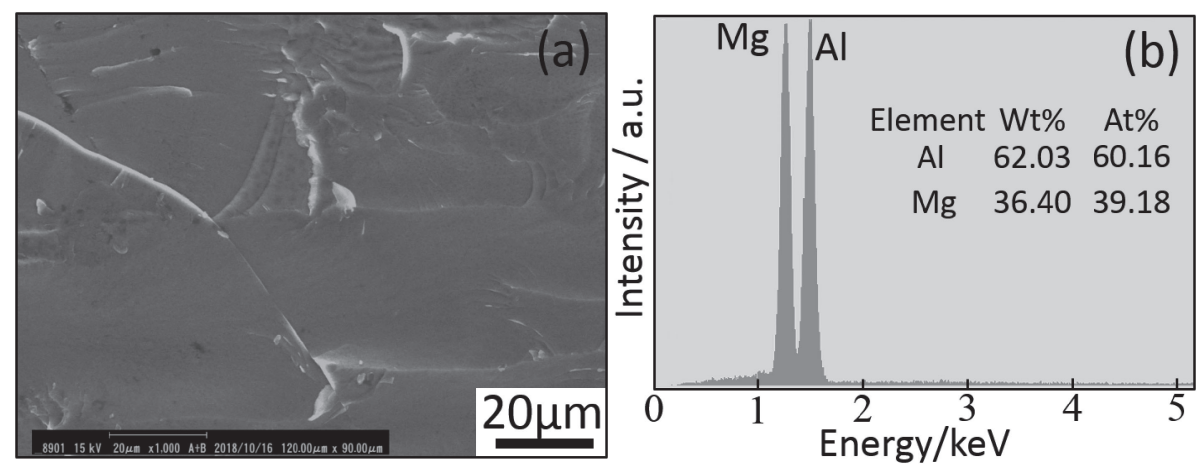

Fig. 4 (a) Morphology of the fracture surface for the Al-Mg interface without the interlayer and (b) EDS analysis from the fracture.
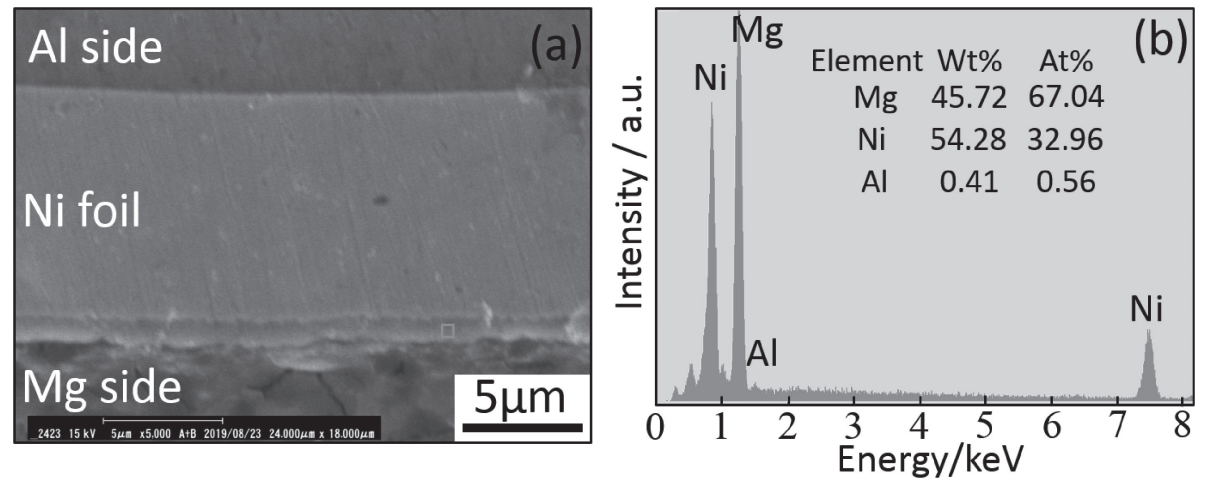

Fig. 5 (a) SEM image of the Al-Mg interface with the Ni foil interlayer after vacuum roll bonding and (b) EDS analysis from reaction layer on the $\mathrm{Mg}-\mathrm{Ni}$ interface.

The SEM image of the interface after vacuum roll bonding using $\mathrm{Ni}$ foil as the interlayer is shown in Fig. 5(a). No reaction layer was observed on the Al-Ni interface. However, a reaction layer with about a $0.9 \mu \mathrm{m}$ thickness was observed on the Mg-Ni interface. Figure 5(b) shows the elemental contents in the $\mathrm{Mg}-\mathrm{Ni}$ interfacial reaction layer. The reaction layer contains almost no $\mathrm{Al}$ element, and the atomic ratio of $\mathrm{Mg}$ to $\mathrm{Ni} 2.03$ is almost equal to the stoichiometric ratio of $\mathrm{Mg}_{2} \mathrm{Ni}$ according to the $\mathrm{Mg}-\mathrm{Ni}$ equilibrium phase diagram. ${ }^{13)}$ Therefore, the $\mathrm{Mg}_{2} \mathrm{Ni}$ intermetallic compound was formed on the $\mathrm{Mg}-\mathrm{Ni}$ interface after vacuum roll bonding. After adding the Ni foil interlayer, the direct contact between the $\mathrm{Al}$ and $\mathrm{Mg}$ sheets was prevented, and the $\mathrm{Al}-\mathrm{Mg}$ intermetallic compounds, $\mathrm{Al}_{3} \mathrm{Mg}_{2}$ and $\mathrm{Al}_{12} \mathrm{Mg}_{17}$, were not observed. In addition, the thickness of $\mathrm{Mg}_{2} \mathrm{Ni}(0.9 \mu \mathrm{m})$ formed on the $\mathrm{Mg}-\mathrm{Ni}$ interface is much smaller than that of the intermetallic compounds $\left(\mathrm{Al}_{12} \mathrm{Mg}_{17}\right.$ of $1.77 \mu \mathrm{m}$ and $\mathrm{Al}_{3} \mathrm{Mg}_{2}$ of $7.76 \mu \mathrm{m}$ ) formed on the $\mathrm{Al}-\mathrm{Mg}$ interface without an interlayer.

Figure 6 displays the distribution of the $\mathrm{Al}, \mathrm{Ni}$ and $\mathrm{Mg}$ elements on the Al-Mg interface with the $\mathrm{Ni}$ foil interlayer after vacuum roll bonding. Similar to the results of Fig. 5, the $\mathrm{Mg}_{2} \mathrm{Ni}$ layer with a $0.9 \mu \mathrm{m}$ thickness was observed on the $\mathrm{Mg}-\mathrm{Ni}$ interface. In addition, the diffusion layers of the $\mathrm{Ni}$ element were observed on both sides of $\mathrm{Mg}$ and $\mathrm{Al}$, and it was obvious that the diffusion rate of $\mathrm{Ni}$ on the $\mathrm{Mg}$ side is much faster than that on the $\mathrm{Al}$ side.

Figure 7(a), (b) shows the fracture surface morphologies of the $\mathrm{Al}-\mathrm{Mg}$ interface with a $\mathrm{Ni}$ foil interlayer after the tensile test. The bonding strength of the interface reached 10.46 MPa. Compared to the interface without any interlayer
$(0.79 \mathrm{MPa})$, the bonding strength of the interface was significantly improved. Most areas of the fracture surface appear to have the morphological characteristics of ductile fracture (area A), and there are some small dimples in the fracture surface. In addition, there are also some morphological characteristics of brittle fracture on the fracture surface (area B). The elemental contents of the $\mathrm{Mg}, \mathrm{Al}$ and $\mathrm{Ni}$ in area $\mathrm{A}$ and area $\mathrm{B}$ are shown in Fig. 7(c) and (d), respectively. Whether in the ductile fracture area $A$ or the brittle fracture area $\mathrm{B}$, the main elements present are $\mathrm{Mg}$ and $\mathrm{Ni}$, and the atomic percentages of $\mathrm{Mg}$ and $\mathrm{Ni}$ in area $\mathrm{B}$ are $59.88 \%$ and $36.48 \%$ respectively, which is close to that of $\mathrm{Mg}_{2} \mathrm{Ni}$. Therefore, the fracture occurred on the $\mathrm{Mg}-\mathrm{Ni}$ interface during the tensile test, and only a small amount occurred in the $\mathrm{Mg}_{2} \mathrm{Ni}$ layer. This indicated that although $\mathrm{Mg}_{2} \mathrm{Ni}$ was formed on the $\mathrm{Mg}-\mathrm{Ni}$ interface, it does not play a major role in the fracture process due to the small layer thickness.

In Fig. 8, the XRD peaks from the $\mathrm{Al}$ and $\mathrm{Mg}$ sides of the fracture surface for the $\mathrm{Al}-\mathrm{Mg}$ interface with $\mathrm{Ni}$ foil interlayer are displayed. In addition to the diffraction peaks of the main elements, there are also diffraction peaks of $\mathrm{Ni}$ and $\mathrm{Mg}_{2} \mathrm{Ni}$ on both sides of the fracture surface. Furthermore, the diffraction peaks of $\mathrm{Mg}$ appear on the $\mathrm{Al}$ side, while the diffraction peaks of $\mathrm{Al}$ are not observed on the $\mathrm{Mg}$ side. These results show that the fracture occurred only on the $\mathrm{Mg}-\mathrm{Ni}$ interface, which is the same as the results obtained in Fig. 7. A schematic diagram of the interface fracture is shown in Fig. 9.

The Mg-clad Al materials with a $\mathrm{Ni}$ foil interlayer were heat treated at $623 \mathrm{~K}\left(350^{\circ} \mathrm{C}\right), 673 \mathrm{~K}\left(400^{\circ} \mathrm{C}\right)$ and $703 \mathrm{~K}$ 

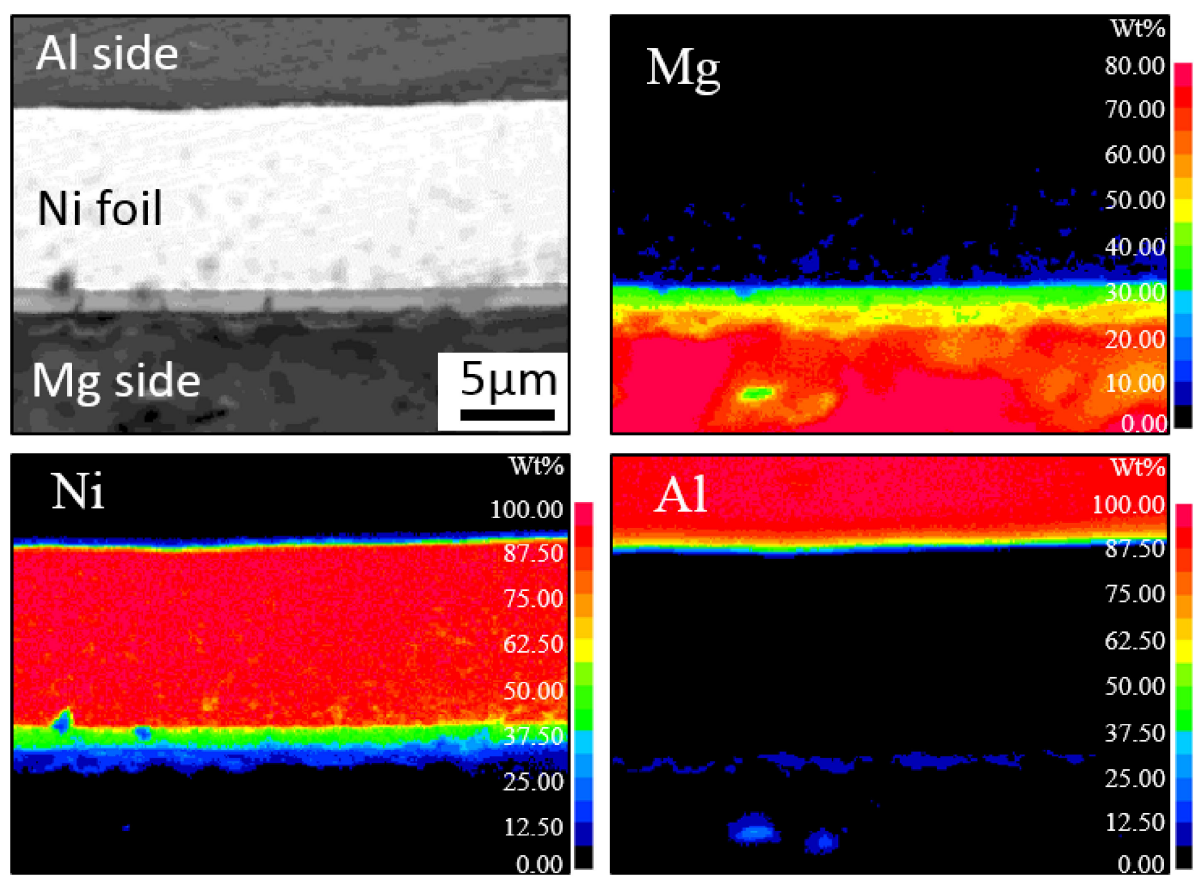

Fig. 6 EPMA area analysis of the $\mathrm{Al}-\mathrm{Mg}$ interface with the $\mathrm{Ni}$ foil interlayer after vacuum roll bonding.
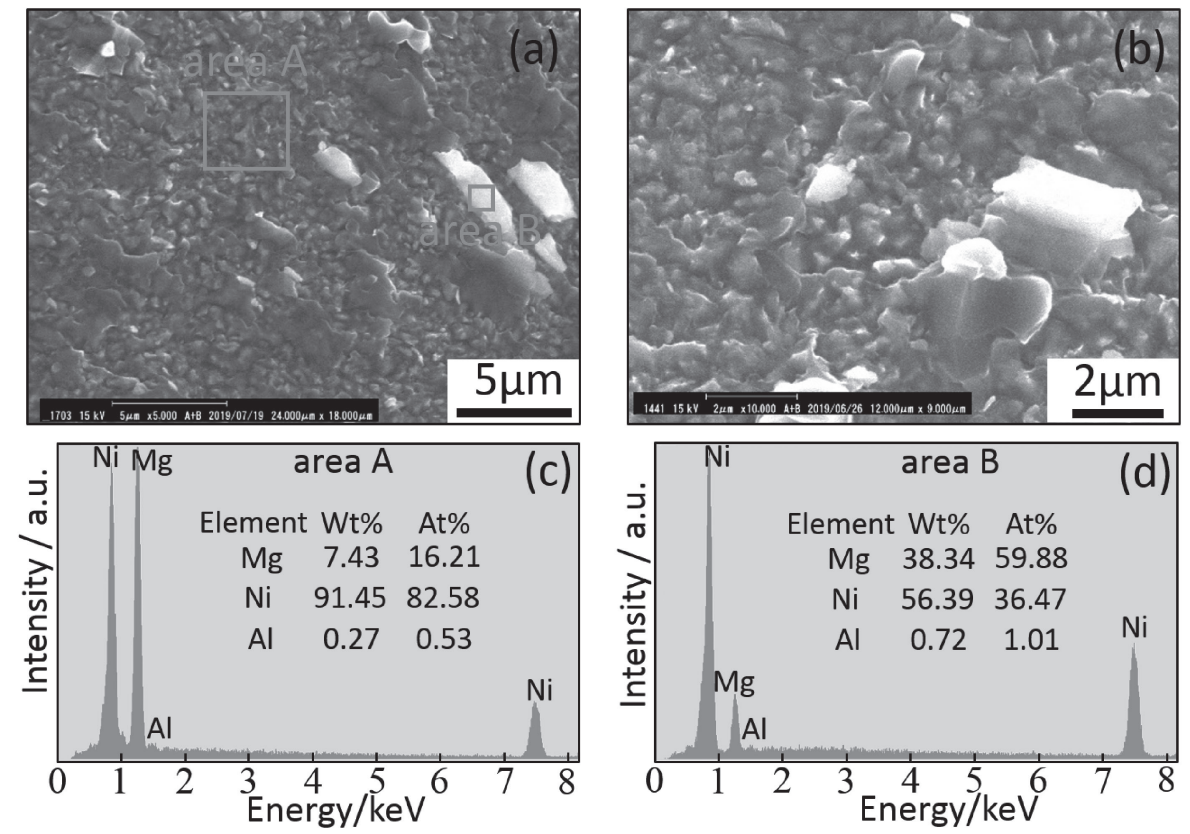

Fig. 7 (a), (b) Fracture surface morphologies of the Al-Mg interface with a Ni foil interlayer; (c), (d) EDS analysis from area A and area B.
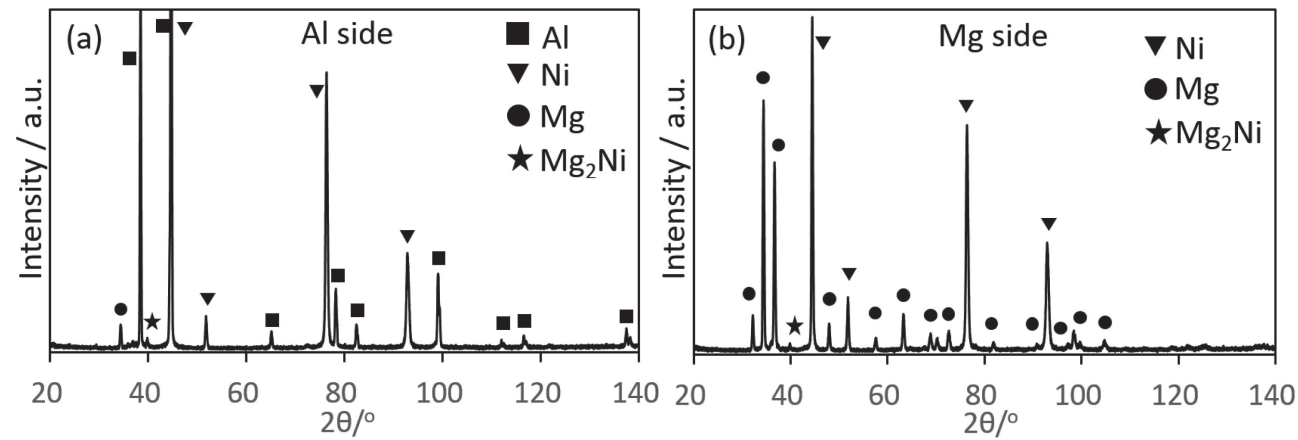

Fig. 8 XRD peaks from the $\mathrm{Al}(\mathrm{a})$ and $\mathrm{Mg}$ (b) sides of the fracture surface for the $\mathrm{Al}-\mathrm{Mg}$ interface with $\mathrm{Ni}$ foil interlayer. 


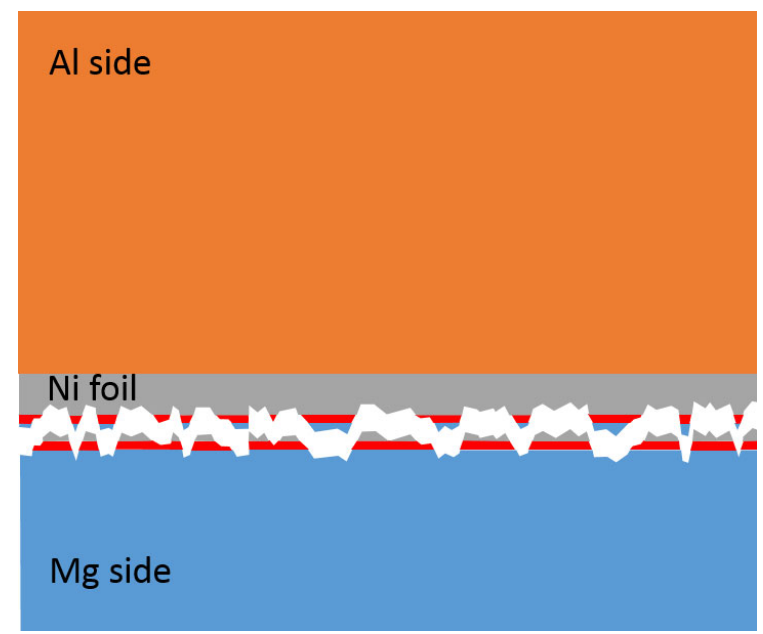

Fig. 9 Schematic diagram of the Al-Mg interface fracture with a Ni foil interlayer.

$\left(430^{\circ} \mathrm{C}\right)$. Figure $10(\mathrm{a})$, (b) shows the SEM image of the interface after heat treatment at $673 \mathrm{~K}$ for $2 \mathrm{~h}$ and $703 \mathrm{~K}$ for $6 \mathrm{~h}$, respectively. The thickness of the reaction layer on the $\mathrm{Mg}-\mathrm{Ni}$ interface grew from $0.9 \mu \mathrm{m}$ to $1.24 \mu \mathrm{m}$ after the heat treatment at $673 \mathrm{~K}$ for $2 \mathrm{~h}$, and no reaction layer was observed on the Al-Ni interface. However, the thickness of the reaction layer on the $\mathrm{Mg}-\mathrm{Ni}$ interface grew from $0.9 \mu \mathrm{m}$ to $7.29 \mu \mathrm{m}$ after heat treatment at $703 \mathrm{~K}$ for $6 \mathrm{~h}$, and a reaction layer with a $2.94 \mu \mathrm{m}$ thickness was also observed on the Al-Ni interface. The EDS line-scanning of the interface was performed, and the results are shown in Fig. 10(c) and (d). The atomic ratio of $\mathrm{Mg}$ to $\mathrm{Ni}$ in the $\mathrm{Mg}-\mathrm{Ni}$ interfacial reaction layer is close to $\mathrm{Mg}_{2} \mathrm{Ni}$ after heat treatment at $673 \mathrm{~K}$ for $2 \mathrm{~h}$ and $703 \mathrm{~K}$ for $6 \mathrm{~h}$, indicating that even after heat treatment at $703 \mathrm{~K}$ for $6 \mathrm{~h}$, the reaction layer on the $\mathrm{Mg}-\mathrm{Ni}$ interface contains only $\mathrm{Mg}_{2} \mathrm{Ni}$. There are two intermetallic compounds, $\mathrm{Mg}_{2} \mathrm{Ni}$ and $\mathrm{MgNi}_{2}$, based on the $\mathrm{Mg}-\mathrm{Ni}$ equilibrium phase diagram. ${ }^{13)}$ The absence of $\mathrm{MgNi}_{2}$ in the reaction layer of the $\mathrm{Mg}-\mathrm{Ni}$ interface indicated that the diffusion temperature was not high enough and the time was not long enough. From Fig. 10(d), in the reaction layer formed on the $\mathrm{Al}-\mathrm{Ni}$ interface after heat treatment at $703 \mathrm{~K}$ for $6 \mathrm{~h}$, the atomic ratio of $\mathrm{Al}$ to $\mathrm{Ni}$ is close to 3, which indicated that the intermetallic compound, $\mathrm{Al}_{3} \mathrm{Ni}$, with a $2.94 \mu \mathrm{m}$ thickness was formed on the $\mathrm{Al}-\mathrm{Ni}$ interface according to Al-Ni equilibrium phase diagram. ${ }^{12}$ )

Figure 11(a) shows the relationship between the $\mathrm{Mg}_{2} \mathrm{Ni}$ thickness and time at different heat treatment temperatures. At any temperature, the thickness of the $\mathrm{Mg}_{2} \mathrm{Ni}$ is proportional to the square root of the time. The thickness of the growing $\mathrm{Mg}_{2} \mathrm{Ni}$ phase after heat treatment can be described by: ${ }^{19)}$

$$
X^{2}=2 D t
$$

where $X$ is the thickness of the $\mathrm{Mg}_{2} \mathrm{Ni}$ layer, $D$ is the growth rate constant and $t$ is the heat treatment time. The growth of $\mathrm{Mg}_{2} \mathrm{Ni}$ clearly followed parabolic kinetics, suggesting that the growth was diffusion controlled. Based on the results of the marker experiments, ${ }^{14)} \mathrm{Mg}$ was the dominant diffusing element in the $\mathrm{Mg}_{2} \mathrm{Ni}$. Using eq. (1) and Fig. 11(a), the growth rate constants $D$ were calculated for each temperature, which were $4.61 \times 10^{-5} \mu \mathrm{m}^{2} / \mathrm{s}, 6.60 \times 10^{-4} \mu \mathrm{m}^{2} / \mathrm{s}, 1.35 \times$ $10^{-3} \mu \mathrm{m}^{2} / \mathrm{s}$ at $623 \mathrm{~K}, 673 \mathrm{~K}$ and $703 \mathrm{~K}$, respectively. There is a linear relationship between $\ln D$ and reciprocal of the temperature, as shown in Fig. 11(b). The temperature dependence of the growth rate constant for $\mathrm{Mg}_{2} \mathrm{Ni}$ should follow the Arrhenius relation expressed by: ${ }^{19)}$

$$
\ln D=-(Q / R) \times(1 / T)+\ln D_{0}
$$

where $Q$ is the growth activation energy, $T$ is the temperature (in kelvin), $R$ is the universal gas constant, and $D_{0}$ is a
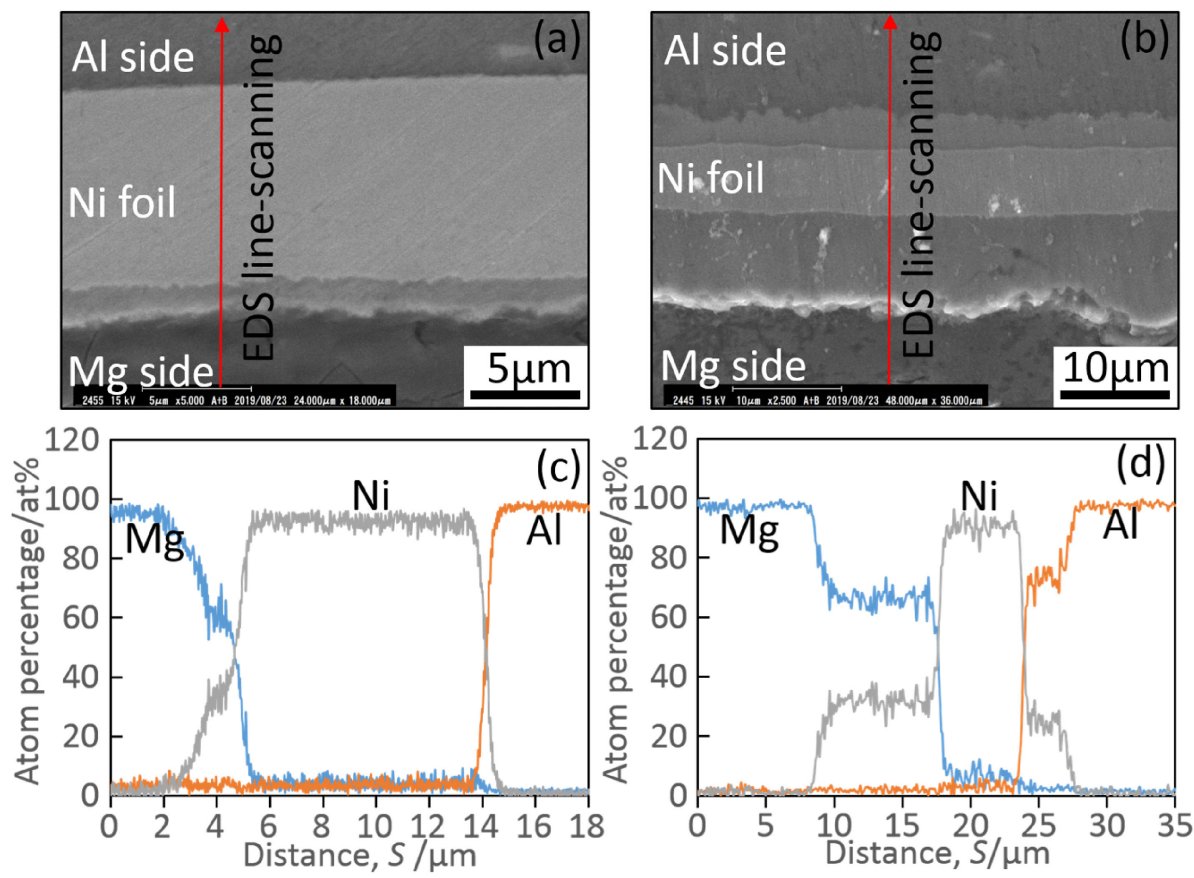

Fig. 10 SEM image and EDS line-scanning profile of the interface after heat treatment for clad materials with the Ni foil interlayer at $673 \mathrm{~K}$ for $2 \mathrm{~h}(\mathrm{a}),(\mathrm{c})$ and $703 \mathrm{~K}$ for $6 \mathrm{~h}(\mathrm{~b}),(\mathrm{d})$. 

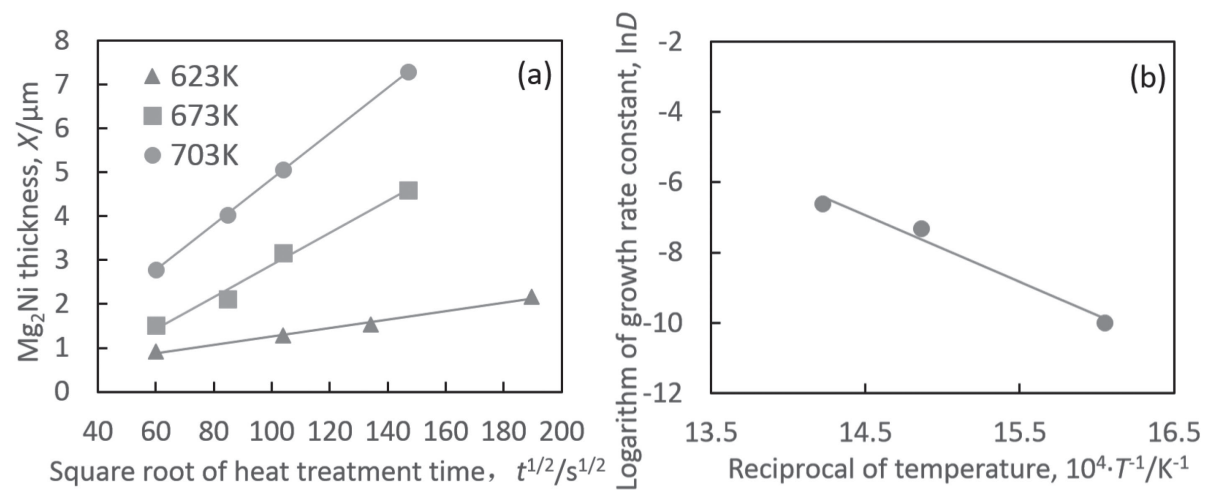

Fig. 11 (a) Relationship between the $\mathrm{Mg}_{2} \mathrm{Ni}$ thickness and time at different temperatures and (b) temperature dependence of the growth rate constant for $\mathrm{Mg}_{2} \mathrm{Ni}$.

constant. The growth activation energy of $\mathrm{Mg}_{2} \mathrm{Ni}$ can be calculated from eq. (2) and Fig. 11(b): $Q=157.24 \mathrm{~kJ} / \mathrm{mol}$. M.Y. Tsai ${ }^{14)}$ studied the solid-solid interfacial reaction in the $\mathrm{Mg}-\mathrm{Ni}$ binary diffusion couples and the reaction temperature was at $673,703,723$, and $753 \mathrm{~K}$. The growth activation energy of $\mathrm{Mg}_{2} \mathrm{Ni}$ was determined to be $120 \mathrm{~kJ} / \mathrm{mol}$. This different result may be due to the different temperature range of the study. The growth activation energy of $\mathrm{Mg}_{2} \mathrm{Ni}$ is greater than that of $\mathrm{Al}_{3} \mathrm{Mg}_{2}\left(85.5 \mathrm{~kJ} / \mathrm{mol}^{16)}\right)$ which mainly affects the interfacial bonding strength, so the $\mathrm{Mg}_{2} \mathrm{Ni}$ layer formed on the interface after vacuum roll bonding was thinner, which improved the interfacial bonding strength.

\section{Conclusions}

The Mg-clad Al materials with a $\mathrm{Ni}$ foil interlayer were prepared by vacuum roll bonding at a $450^{\circ} \mathrm{C}$ rolling temperature and $25 \%$ reduction. No intermetallic compound was formed on the $\mathrm{Al}-\mathrm{Ni}$ interface, and the $\mathrm{Mg}-\mathrm{Ni}$ interface formed the intermetallic compound $\mathrm{Mg}_{2} \mathrm{Ni}$ layer with a $0.9 \mu \mathrm{m}$ thickness, which was smaller than that of the intermetallic compounds (about $10 \mu \mathrm{m}$ ) formed on the $\mathrm{Al}-$ $\mathrm{Mg}$ interface without an interlayer. Compared to the Mg-clad Al materials without any interlayer, the bonding strength of the interface increased from $0.79 \mathrm{MPa}$ to $10.46 \mathrm{MPa}$. The main reason is that the growth activation energy of $\mathrm{Mg}_{2} \mathrm{Ni}$ $(157.24 \mathrm{~kJ} / \mathrm{mol})$ is greater than that of $\mathrm{Al}_{3} \mathrm{Mg}_{2}$ which mainly affects the $\mathrm{Al}-\mathrm{Mg}$ interfacial bonding strength, and there is no overly thick intermetallic compound layer on the interface.

\section{REFERENCES}

1) Z.P. Gu, Y.Z. Huang, Y. Wang, N.Y. Yuan and J.N. Ding: Mater. Lett. 252 (2019) 304-307.

2) T.M. Pollock: Science 328 (2010) 986-987.

3) H.A. Patel, D.L. Chen, S.D. Bhole and K. Sadayappan: J. Alloy. Compd. 496 (2010) 140-148.

4) H. Haferkamp, R. Boehm, U. Holzkamp, C. Jaschik, V. Kaese and M. Niemeyer: Mater. Trans. 42 (2001) 1160-1166.

5) Y. Yoshida, L. Cisar, S. Kamado and Y. Kojima: Mater. Trans. 43 (2002) 2419-2423.

6) K.S. Lee, J.S. Kim, Y.M. Jo, S.E. Lee, J. Heo, Y.W. Chang and Y.S. Lee: Mater. Charact. 75 (2013) 138-149.

7) H.L. Yu, C. Lu, A.K. Tieu, A. Godbole, L.H. Su, Y. Sun, M. Liu, D.L. Tang and C.L. Kong: Sci. Rep. 3 (2013) 2373.

8) X.P. Zhang, T.H. Yang, J.Q. Liu, X.F. Luo and J.T. Wang: J. Mater. Sci. 45 (2010) 3457-3464.

9) H. Matsumoto, S. Watanabe and S. Hanada: J. Mater. Process. Technol. 169 (2005) 9-15.

10) Q. Wang, X.S. Leng, J.C. Yan, W.B. Guo, Y. Fu and T.M. Luan: J. Mater. Sci. Technol. 29 (2013) 948-954.

11) Z.W. Xu, Z.W. Li, J.Q. Li, Z.P. Ma and J.C. Yan: Ultrason. Sonochem. 46 (2018) 79-88.

12) C. Colinet, P. Hicter and A. Pasturel: Phys. Rev. B 45 (1992) 15711580 .

13) C.L. Tsao and S.W. Chen: J. Mater. Sci. 30 (1995) 5215-5222.

14) M.Y. Tsai, M.H. Chou and C.R. Kao: J. Alloy. Compd. 471 (2009) 9092.

15) S.B. Jung, Y. Minamino, T. Yamane and S. Saji: J. Mater. Sci. Lett. 12 (1993) 1684-1686

16) S. Brennan, K. Bermudez, M.S. Kulkarni and Y. Sohn: Metall. Mater. Trans. A 43 (2012) 4043-4052.

17) J.L. Murray: Bull. Alloy. Pha. Diag. 3 (1982) 60-74.

18) I.K. Kim and S.I. Hong: Metall. Mater. Trans. A 44 (2013) 3890-3900.

19) C.J. Li, Z.J. Yuan, R. Guo, W.D. Xuan, Z.M. Ren, Y.B. Zhong, X. Li, H. Wang and Q.L. Wang: J. Alloy. Compd. 641 (2015) 7-13. 